\title{
CARBON DIOXIDE EMISSIONS FROM SHIPPING OPERATIONS INFLUENCES LIGHTNING IN NIGERIA’S COASTAL REGION
}

\author{
AKPOYIBO, F.E ${ }^{1}$, EZECHUKWU, A.O ${ }^{2}$ \\ Department of Electrical/Electronic Engineering, Nnamdi Azikiwe University, Awka, Anambra State, Nigeria ${ }^{1}$ \\ Department of Electrical/Electronic Engineering, Nnamdi Azikiwe University, Awka, Anambra State, Nigeria ${ }^{2}$
}

\begin{abstract}
Diesel engines from vessels employed for shipping operations produces carbon dioxide $\left(\mathrm{Co}_{2}\right)$ emissions forming clouds in the atmosphere. As particulates accumulates and collides in the cloud, static electricity is formed. When the positive and negative charges meet, the resulting great spark is what is termed lightning. Lightning related fatalities and damages persists within the Nigerian coastal lines. The focus of this paper is to investigate why in Nigeria, shipping routes measuring about $750 \mathrm{~km}$ experiences more lightning than some other regions. Secondary sources were used. The study reveals that the flash densities along the sea routes are higher, hence, high frequency of lightning incidents.. The paper posit that Nigeria Maritime Administration and Safety Agency (NIMASA) in collaboration with the International Maritime Organization (IMO) should strategies agenda with a view to reducing $\mathrm{Co}_{2}$ emission from vessels entering Nigeria seaports as part of environmental protection efforts.
\end{abstract}

Keywords: Coastline, electricity, emission, lightning, ports, shipping,

\section{INTRODUCTION}

Carbon dioxide is defined as a colourless gas with faint odour as well as sour taste. It is within the family of greenhouse gases. Greenhouse gas is any gas that absorbs and reradiates infrared radiation emissions from the earth's surfaces [1]. $\mathrm{Co}_{2}$ can be produced during combustion of certain fuels [2] $\mathrm{Co}_{2}$ accumulation in the atmosphere contributes towards cloud formation. Ships engines used for maritime transportation also produce $\mathrm{Co}_{2}$ emissions which in turn causes increase in cloud density.. At a point, charge separation occurs in the cloud and when the positive and negative charges contacts, a big spark takes place known as lightning.

Maritime transport is the transport of people (passengers) or goods (cargo) through waterways. Transport by water is cheaper compared to other methods, [3][4]. Maritime shipping transports carriers $90 \%$ of the goods traded around the world by volume contributing almost $3 \%$ of the world's carbon dioxide emission and the International Maritime Organization predicts carbon dioxide emission may increase to $250 \%$ by 2050 [5].. Secondary sources were used. The paper investigates how lightning is more intense along shipping routes in Nigeria with associated fatalities.

\section{CARBON DIOXIDE EMISSION}

$\mathrm{Co}_{2}$ is a major contributor towards global warning which leads to ozone depletion as particulates are introduced into the atmosphere, hence; assist in formation of cloud culminating into lightning. About $70 \%$ of $\mathrm{Co}_{2}$ emissions occur within $400 \mathrm{~km}$ from the coast in Nigeria, particularly, at the ports due to vessels engines burning diesel fuel [6][3]. Among various types of vessels, Premium Motor Spirit (PMS) carriers are the heaviest emitters of $\mathrm{Co}_{2}$, followed by the container vessels and general cargo vessels.

Result for the first and second quarters of 2017 indicate that approximately 16,335 ton and 773 ton of CO2 emitted during anchorage and while passing through lock gates movement, respectively within Lagos and Tin Can Island Ports. Similarly, 644 ton of $\mathrm{Co}_{2}$ emitted through maneuvering to the dock movements, accounting for $85 \%$ of the total $\mathrm{Co}_{z}$ emissions [6]. Container ships tend to follow indirect routes, making more stops over shorter distances in order to load and unload containers, thereby generating more emissions [7]. 
International Journal of Innovative Research in Electrical, Electronics, Instrumentation and Control Engineering

\author{
Impact Factor 7.047 Vol. 10, Issue 2, February 2022
}

DOI: $10.17148 /$ IJIREEICE.2022.10220

\title{
ESTIMATING EMISSIONS AND THE ENVIRONMENT
}

Emissions from ships come from main engines, auxiliary engines, and boilers. [8]. Maritime transport accounts for between $3.5 \%$ to $4 \%$ of climate change emissions, basically carbon dioxide. [9][10]. There is every need to reduce $\mathrm{Co}_{2}$ emission ostensibly to achieve clean environment. The International Maritime Organization in 2018 proposed that, by 2050 it could be possible to decrease emission to 50\% [11]. Shipping caused emissions including greenhouse gas may rise to $50-250 \%$ if authorities concern fail to apply approved Co2 emission reduction technologies [12]. NIMASA proposes that ships emitting carbon dioxide will not be allowed at the Nigerian seaports as such emission to the atmosphere affects the climate negatively [13]

\section{DIESEL EXHAUST}

Marine diesel engines produce $\mathrm{Co} 2$ which depletes the ozone layer [14]. A forecast of rise in shipping emissions between $35 \%$ and $210 \%$ by 2050 , but, lack of reliable data on the emissions being released, couple with disputed methods made it difficult to assign responsibility for those emissions to countries (Trimmer and Goder, 2019). Diesel contains more carbon, hence, produces more $\mathrm{Co} 2$ for a given volume of fuel during combustion culminating into a litre producing $2.66 \mathrm{kgCo} 2$ [15]. Some diesel engines may be up to a four-storey building having capabilities above 100,000 - 300,000 horsepower) [16]. Figures 1 and 2 illustrates Co2 emission from vessels.

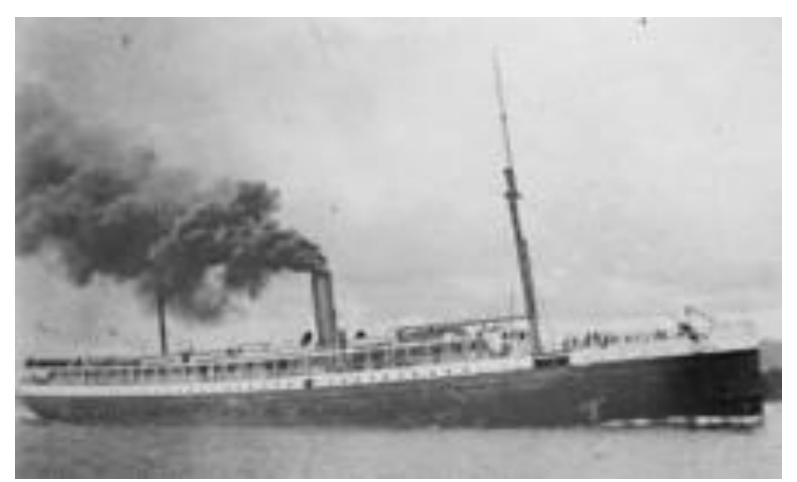

Figure 1. A steam ship “Columbia” Source: [17]

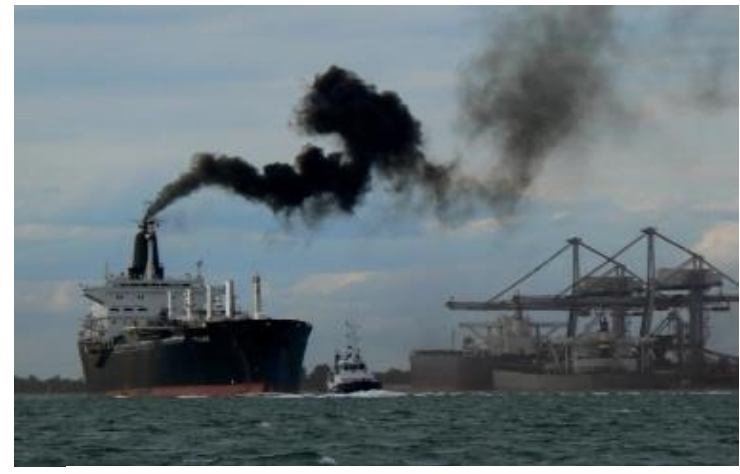

Figure. 2 Carbon dio oxide emissions, Source: [16]

\section{SHIP SPEED}

Design speed of bulker ships is usually above $13.5-15$ knots $(25.0-27.3 \mathrm{~km} / \mathrm{h}$, while container ship speed is about $24 \mathrm{knot}$ and the average speed of a container speed is $18-24 \mathrm{knot}(33.3-37.0 \mathrm{~km} / \mathrm{hr})$ [18]. Generally, the average speed of ocean liners is about 15 knots $(1$ knot $=1$ marine mile $=1,853$ metres [19]. Ship speed is measured with the aid of Global Positioning System (GPS) consisting of a transmitter, receiver and Satellite system [20]..The largest ships are speeding up and emitting more Green house Gasses (GHGs). However, the largest container and oil tanker speeds less with low efficiency, emitting more $\mathrm{CO} 2 / \mathrm{dwt}-\mathrm{nm}$ implying that emissions will continue to rise.[21]

\section{LIGHTNING}

Diesel emissions from ships cause twice as many lighting strikes along the world's busiest shipping lanes, according to a study published in Geophysical Research Letters Scientists using lightning strike data collected over shipping lanes in the northeastern Indian Ocean and the South China Sea, where emissions are the highest globally[22]. Emissions from diesel powered ships contribute immensely to lightning strikes [23]. According to [24], there were more lightning strikes around oceans and seas used by ships. Pollution from boats (shipping) does trigger lightning [25] In [26], fumes from ship trigger extra lightning. Joel Thornton and others at the University of Washington in Seattle records lightning strikes between 2005 and 2016 from the World Wide Lightning Location Network concluded that there were more lightning strikes following two straight lines in the open oceans, which coincided with two of the busiest shipping lanes in the world leading to more intense thunderstorms [27].

Cargo ships introduces exhaust into clouds producing lighting strikes [28]. Studies shows that lightning strikes occur almost twice as above busy shipping lanes. [26]. American Geophysical Union journal collated global lightning stroke data for 12 years reveals that the density of lightning doubled over shipping lanes [29].. The National Association of Space Administration (NASA) satellite instrument MODIS demonstrated that ship track clouds causes lightning over 
International Journal of Innovative Research in Electrical, Electronics, Instrumentation and Control Engineering

Impact Factor $7.047 \div$ Vol. 10, Issue 2, February 2022

DOI: $10.17148 /$ IJIREEICE.2022.10220

the Pacific Ocean (Shepherd, [29]. By comparing the lightning data with maps of ships' exhaust emissions they reveals that there were nearly twice as many lightning strikes along the main shipping routes [26],

\section{FLASH DENSITY ALONG SHIPPING ROUTES IN NIGERIA}

Studies carried out on frequent lightning strike in Nigeria concludes that flash density along the coastline (shipping routes) of Nigeria is higher than some other areas correlating with literature, [30] found out that the Flash Density could be 10 to 15 flashes/km2/year around Brass area in Bayelsa State, Nigeria. Similarly, [31] stated that the coastal regions in Nigeria strike density could be as high as 15 flashes/km2/year. According to [32],

Calabar area in Nigeria records lightning flash density 47.3 using Optical Transient Detector (OTD) and Lightning Imaging Sensor (LIS). Port-Harcourt and Burutu port areas also experiences high frequency of lightning incidents with catastrophic consequences.

\section{DATA COLLATION}

Data from the following sources were collected: cargo traffic statistics revealed a total of 71,903,266 recorded at all Nigerian ports in 2017 [33]. Nigeria has a coastline of over 750km [34]. Onne ports handled about 80\% of total outward cargoes, followed by Delta and Apapa ports respectively [35]. According to [36] distance within some Nigerian coastline ports include; Calabar to Lagos 428 Nautical miles, Onne to Lagos, 359 Nautical miles and Burutu to Lagos, 227 Nautical miles.

In [37] the total number of ships received in Nigerian Ports during 2019 and 2020 reveals that in 2019, the total figure was 4,251 and in 2020 the number reduced to 3,972.. Bulk and container ships were selected for analysis. Bulk carrier produces 440 emission in million metric tons $\mathrm{Co} 2$ per kilometre while container ships contributes 140 emissions in million metric tons per kilometre [38]. Assume 60\% of the vessels received in Nigeria ports during 2019 and 2020 were container ships, meaning that in 2019, the ports received 2,551 and in 2020, the number was 2,413. While the bulk carrier ships $40 \%$ in 2019 translating to 1,700 and 2020 gives 1,589 respectively.

\section{CALCULATIONS}

Calculating $\mathrm{Co} 2$ emission from ships could be derived from the following expressions

Emissions can be calculated as expressed in [39]

$E_{i j}=E F_{i j} \times L F_{j k} \times \frac{K W j}{\eta_{j}} \times T_{j k}$

(1)

Where

$\mathrm{E}_{\mathrm{ijk}}=$ emissions of $\mathrm{CO}_{2}(\mathrm{i})$ from vessels $\mathrm{j}$ on route $\mathrm{k}$ in $\operatorname{gram}(\mathrm{g})$

$\mathrm{EF}_{\mathrm{ij}}=$ emissions factor for emission of $\mathrm{CO}_{2}$ (i) from vessels $\mathrm{j}$ on route $\mathrm{k}$ in $\operatorname{gram}(\mathrm{g} / \mathrm{kwh})$

$\mathrm{LF}_{\mathrm{jk}}=$ average engine load factor for vessel $\mathrm{j}$ on route $\mathrm{k}$

$\mathrm{Kw}=$ rated main engine power in kilowatts $(\mathrm{kw})$ for vessel $\mathrm{j}$, nj engine efficiency

$\mathrm{T}_{\mathrm{jk}}=$ duration of travel for vessel $\mathrm{j}$ on route $\mathrm{k}$ in hour $(\mathrm{h})$

Co2 emission may also be calculated by multiplying the distance travelled between ports and the number of containers for that shipment [40] i.e distance travelled $\mathrm{x}$ number of containers

(2)

The number of ship's capacity $\mathrm{x}$ number of containers carried $\mathrm{x}$ speed

No. of vessels x Co2 emission (constant) x distance travelled (Adenubi,2021)

(3)

\section{RESULTS AND DISCUSSION}

Table.1 Number of vessels that berthed at Delta and Calabar ports from 2912-2017. Source: (NBS,2018)

\begin{tabular}{|l|l|l|l|l|l|l|l|l|}
\hline Delta Ports & 2012 & 2013 & 2014 & 2015 & 2016 & 2017 & 2019 & 2020 \\
\hline No. of Vessels & 367 & 609 & 603 & 528 & 438 & 507 & 6,827 & 1,224 \\
\hline Calabar Port & 2012 & 2013 & 2014 & 2015 & 2016 & 2017 & & \\
\cline { 1 - 6 } No. of Vessels & 157 & 373 & 269 & 306 & 453 & 174 & & \\
\hline
\end{tabular}


International Journal of Innovative Research in Electrical, Electronics, Instrumentation and Control Engineering

Impact Factor 7.047 Vol. 10, Issue 2, February 2022

DOI: $10.17148 /$ IJIREEICE.2022.10220

Table.2 Co2 Emission using constants for two years (2019-2020) from equation 4

\begin{tabular}{|l|l|l|l|l|l|l|}
\hline Year & Vessel & $\begin{array}{l}\text { No. of } \\
\text { Vessels } \\
\text { involve }\end{array}$ & Constant & $\begin{array}{l}\text { Co2 Emission } \\
\text { In Million ton } \\
\text { per km }\end{array}$ & $\begin{array}{l}\text { Distance } \\
\text { (Km)-Lagos } \\
\text { to Calabar }\end{array}$ & $\begin{array}{l}\text { Total } \\
\text { emission } \\
\text { million tnn/km }\end{array}$ \\
\hline 2019 & $\begin{array}{l}\text { Container ship } \\
60 \%\end{array}$ & 2,551 & 140 & 357,140 & 428 & $152,855,920$ \\
\hline $\begin{array}{l}\text { Bulk carrier } \\
40 \%\end{array}$ & 1,700 & 440 & 740,000 & 428 & $316,780,000$ \\
\hline 2020 & $\begin{array}{l}\text { Container ship } \\
60 \%\end{array}$ & 2,413 & 140 & 337,820 & 428 & $\mathbf{4 6 9 , 6 3 5 , 9 2 0}$ \\
\hline $\begin{array}{l}\text { Bulk carrier } \\
40 \%\end{array}$ & 1,589 & 440 & 699,160 & 428 & $144,588,960$ \\
\hline & & & & & $299,240,480$ \\
\hline
\end{tabular}

Consequently, regulatory bodies, vessel owners and builders need to apply available modern technology to secure $\mathrm{Co}_{2}$ reduction and more efficient shipping operation. [16].

\section{DISCUSSION OF RESULTS}

Figures 1 and 2 illustrate ships emitting Co2 and Sulphur dioxide thereby polluting the atmosphere..

Table 1 shows the number of vessels that arrived Delta and Calabar ports from 2012 to 2020. This indicates that enormous quantity of carbon dioxide must have been emitted into the coastal areas leading to cloud formation along the shipping routes which increase lighting strikes, due to high flash density correlating with literature

Table 2 reveals that in 2019, $\mathrm{Co}_{2}$ emitted into the atmosphere following shipping operations was 469,685,920 million tons. Similarly, in $2020, \mathrm{Co}_{2}$ emission along the Nigerian coatal region was $443,829,440$ million tons caused by ships plying the route.

\section{CONCLUSION AND RECOMMENDATION}

\section{Conclusion}

The paper presented how Carbon dioxide emission from ships influences on lightning along Nigeria's coastal region. Vessels entering Nigerian ports data analyzed and calculations carried out to ascertain $\mathrm{Co}_{2}$ emission in million ton/km into the atmosphere forming clouds culminating into lightning. The result shows enormous $\mathrm{Co}_{2}$ emissions along the shipping routes in Nigeria leading to flash density more intense at the ports which increases the frequency of lightning correlating with global trend where shipping lanes experiences as much as twice lightning strikes than some others regions..

\section{Recommendation}

1. $\mathrm{Co}_{2}$ emission reduction technologies must be employed by bodies such as NIMASA, IMO and Ship owners in order to decrease lightning frequency as well as protection of the environment.

2. Further research into flash density levels (values) along shipping routes and also at the sea ports in Nigeria's coastal region employing modern equipments becomes necessary for better understanding of the concept.

\section{REFERENCES}

[1] Britannica (2022), Definition,Formula,Uses and Facts. Britannica. http://www.britainnica.com

[2] Merriam-Webster Dictionary (2022), Definition of Carbon dioxide. Merriam-Webster, Incorporated http://www.merriam.webster.com

[3] Pereira, M and Oliveira, U.C (2015) Maritime Transport and Climate Change. https;//www.un.org/depts./los/Nippon/unuff_programme_home_alumni/2015_laca

presentations/10_PrereiraOliveira.pdf

[4] Ogbonnaya,E.A, Poku, R, Adigio E.M ?(2013) Effects of Greenshipping to the Maritime Industry, ETASR Engineering, Technology \& Applied Science Research Vol. 3,_o. 2, 2013, 402-407 p. $402-407$ 
International Journal of Innovative Research in Electrical, Electronics, Instrumentation and Control Engineering

\author{
Impact Factor 7.047 Vol. 10, Issue 2, February 2022 \\ DOI: $10.17148 /$ IJIREEICE.2022.10220
}

[5] Selin,H and Cowing, R (2018) Cargo Ships are boatloads of Carbon and nobody wants to take blame. Phys.org 2003-2020

[6] Olukanni, D.O and Esu, C.O (2018) Estimating greenhouse gas emissions from port vessel operations at the Lagos and Tin Can ports of Nigeria. Olukanni \& Esu, Cogent Engineering (2018), 5: 1507267 https://doi.org/10.1080/23311916.2018.1507267

[7] Trimmer, C and Goder, J (2019) Calculating Maritime Shipping emissions per-traded Commodity. Stockhelm Environment Institute, Brazil. https://www.sei.org/publications/shipping-emissions-per-commodity/

[8] Olmer, N, Comer, B. Roy, B. Mao,X. and Rutherford, D (2017) Greenhouse Gas Emissions From Global Shipping, 2013-2015, International Council on Clean Transportation 1225 I Street NW, Suite 900 Washington DC 20005 USA communications@theicct.orgwww.theicct.org|@TheICCT

[9] Walker TR, Adebambo O, Del Aguila Feijoo MC, Elhaimer E, Hossain T, Edwards SJ, Morrison CE, Romo J, Sharma N, Taylor S, Zomorodi S (2019). "Environmental Effects of Marine Transportation". World Seas: An Environmental Evaluation.pp. 505-530. doi:10.1016/B978-0-12-805052-1.00030-9. ISBN 978-0-12-805052-1.

[10] Vidal, J (9 April 2009). "Health risks of shipping pollution have been 'underestimated'". The Guardian. Retrieved 3 July2009.)

[11] UNCTAD (2018), UNCTAD Communications and Information Unit, Geneva, Switzerland E: unctadpress@unctad.org. Web: unctad.org/press

[12] Third IMO GHG Study (2014) PDF, International Maritime Organization.

[13] Uko, N.A (2017), NIMASA to Bar Carbon Emitting Ships From Nigerian Ports. Ship Young. http://www.youngship.com.news

[14] US Environmental Protection Agency (EPA) (2003), Washington, DC. "Control of Emissions From New Marine Compression-Ignition Engines at or Above 30 Liters Per Cylinder." Final rule. Federal Register, $68 \underline{\text { FR }} \underline{9751}, 2003$

[15] National Resources Canada (2014), Learn the Facts: Fuel consumption and Co2 . National Resources Canada. droitdaur@nrcan-mcan.gc.ca

[16] Marine \& Petroleum Nigeria (2019), Sulphur 2020-Cutting sulphur Oxide emissions, Marine \& Petroleum Nigeria, http://www.marineandpetroleum.com/content/sulphur-2020---cutting-sulphur-oxide-emissions

[17] Belyk, Robert C. (2001) Great Shipwrecks of the Pacific Coast.New York: Wiley, 2001.Print.ISBN 0-471-38420-8

[18] Gillewater, $\mathrm{M}$ and Barbour, W (1997), $\mathrm{Co} 2, \mathrm{CH}_{4}$ and $\mathrm{N}_{2} \mathrm{O}$ Emissions from transportation water $-\mathrm{Borne}$ Navigation, International Conference on Air Pollution Prevention 15-16 September, 1997 Brazil.

[19] Rodrigue, J.P, Notteboom, T and Slack, B (2019), Maritime Transportation. Ean-Paul Rodrigue, Dept. of Global Studies and Geography, Hofstra University, New York, USA.

[20] Agarwal, M (2020), What is the speed of a Ship at sea? Marine Insight. $\underline{\text { http://www.marineinsight.com/speed-of-a-ship-at-sea/ }}$ [21] Olmer,N, Comer,B, Roy, B, Mao,X and Rutherford, D (2015) Greenhouse Gas Emissions Global Shipping, 20132015, International Council of Clean Transportation (icct), 12251 Street NW, Suite 900, Washing DC 20005 USA communications@theicct.org@TheICCTwww.theicct.org

[22] Maritime Information Services (2017) Cargo Ships Cause Lighting Strikes Maritime Information Services Ltd. http://www.portechnology,

[23] Daley, J (2017) Cargo Ships May Double Lightning Strikes in Their Path, Smithsonian.com Cargo Ships May Double Lightning Strikes in Their Path_smart News_Smithsonian.pdf- Adope Reader

[24] Sputnik (2018), Lightning Strikes Triggered by Human Shipping Activity, Research Finds. SPUNIK International

[25] Pierre-Louis, K. (2017)Our pollution might actually be causing thunderstorms : Ships could seed clouds for lightning ; Popular Science. A Bonnier Corporation Company.

[26] Ravilious, K (2018) Ships' fumes a trigger for more lightning strikes, Gardian News and Media Limited.

[27] Supriya, L (2018) Lightning storms triggered by exhaust from cargo ships, Magazine issue 3144

[28] Perkins, S (2018) Cargo ships may be creating lightning at sea. American Association for the Advancement of Science. https://ecoscore.be/en/info/ecoscore/co2 Retrieved 23/02/2020

[29] Shepherd, M,(2018). Cargo Ships May Be Causing More Lightning - University of Georgia's (UGA) Atmospheric Sciences Program. Dr. Shepherd is the Georgia Athletic Association

[30] Afa, J.T and Kelvin,B.A (2013), Ground Flash Density of the Brass Coast of Nigeria, $1^{\text {st }}$ Annual International Interdisciplinary Conference, AIIC 2013, 24-26 Ap

[31] Melodi A. O.1, Oyeleye M. O. 2017. Modeling of Lightning Strike Events, and Correlation with Power Outages in South-West Coast, Nigeria International Journal of Electrical and Computer Engineering (IJECE) Vol. 7, No. 6,December 2017, pp. 3262 3270 ISSN: 2088-8708, DOI: 10.11591/ijece.v7i6.pp3262-3270

[32] Christian (2003), Measured Lightning Activity Worldwide, National Lightning Safety Institute, 891 N, Hoover Ave. Louisville, Co 80027 USA 


\section{IJIREEICE}

International Journal of Innovative Research in Electrical, Electronics, Instrumentation and Control Engineering

Impact Factor $7.047 \div$ Vol. 10, Issue 2, February 2022

DOI: $10.17148 /$ IJIREEICE.2022.10220

[33] Nigeria Bureau of Statistics (2017), Nigerian Ports Statistics, Nigeria Bureau of Statistics, Plot 762 Independence Avenue Central Business District, FCT, Abuja, Nigeria.

[34] Momoh, B.C. (2013), An Analysis of Nigerian Seaborne Trade (Dry Bulk) and the Demand for Transport. International Affairs and Global Strategy www.iiste.org ISSN 2224-574X (Paper) ISSN 2224-8951 (Online) Vol.15, 2013

[35] Nigeria Bureau of Statistics (2018), Nigerian Ports Statistics 2012-2017 Report, Nigeria Bureau of Statistics, Plot 762 Independence Avenue Central Business District, FCT, Abuja, Nigeria.

[36] Ports.com (2018), Ports of Onne, Calabar and Burutu to Lagos Apapa Port, Nigeria. Ports.com http://www.ports.com/sea https://www.nimasa.gov.ng/pdfs/nigerian maritime industry forecast.pdf

[37] Adenubi, T (2021) Lagos Ports Witness Drop in Container Ships Traffic in 2020-NPA . The Nigerian Tribune (Feb.22, 2021) http://tribuneonline.ng.com. LagosTisco, I (2021), Co2 emission in international shipping 2020. Statisla. http://www.statiscla.com

[38] Tisco, I (2021), Co2 emission in international; shipping. Statista. http://www.statista.com [39] ACCESS (2014), Calculation of fuel consumption per mile for various ship types and ice conditions in past, present and in the future. Seventh Framework Programme. www.access-eu.org

[40] BSR (2015), How to calculate and Manage Co2 Emissions from Ocean Transport. http://www.bsr.org 